\title{
Farm Policy: Justifications, Failures and the Need for Reform
}

\author{
Thomas Gale Moore
}

\begin{abstract}
A U.S. economy. It accounts for about 18 percent of our GNP, a share larger than manufacturing. Because of its size, policies that affect fam prices and output have wide-ranging effects, not only on U.S. farmers, but on foreign producers and consumers as well. For policies with effects this broad, it certainly is important to understand why they exist and the effects they have.

The general philosophical background behind our agricultural policy is largely the same as that being followed in most western countries: to increase the size and prosperity of the farm sector. It is interesting to note immediately that this philosophy is quite different in Third World countries where the objective is to tax agriculture. The reason for this philosophy, of course, is that the small urban population can exploit the more numerous rural population. In developed countries, the small agricultural population exploits the larger nonmural group. These results illustrate the public choice proposition that small groups are often in a position to tax the more general population.
\end{abstract}

\section{WUSTIFICATONS FOR FARM POLICRES}

The case for government support of agricultural policies has several justifications. Basically, we go back to the 1930s, to the Great Depression, for the start of a major intervention by the federal government into agriculture. At that time, U.S. agriculture was de-

Thomas Gale Moore is a member of the Council of Economic Advisers. This paper was presented at the meeting of the Federal Resenve System Committee on Agriculture and Rural Development held at the Federal Reserve Bank of St. Louis on May 21, 1987. pressed by a combination of low product prices, increasing debt burdens and soil erosion due to drought. A major justification for aiding distressed farmers was based on the idea of equity. Traditionally, US. society has been based on the idea of a fair distribution of wealth. Equity is good. Disparity is bad. Farm income has lagged behind urban incomes for many decades, and concern over economically disadvantaged farmers lay behind much of the support for doing something. This is a pure income transfer argument that is becoming less and less tenable as the absolute size of all payments rises and the distribution of payments, which is based on production, falls largely on the wealthy (see table 1). Is it equitable today to transfer $\$ 250,000$ in deficiency payments to a farmer when he is worth $\$ 2$ million?

Another justification for aiding farmers is the hypothesized existence of market failures. In fact, most of the recent focus on aiding farmers has been not on agriculture's relative poverty but the difficulty of managing farms in a risky and uncertain environment. The assertion is that farming not only is more risky than other businesses, but mechanisms for hedging that risk are not available in conventional private markets. Thus, govemment programs have been justified in terms of reducing risks, especially risks of nature, such as drought or flood. Other factors, such as low price elasticities of demand and supply and biotechnological change also contribute to an inherent riskiness and uncertain environment faced by agricultural producers. Wide variation in commodity prices and production are offered as evidence to justify the design of price support programs and crop insurance.

Granting that these farming lisks exist, however, does not necessarily justify government intervention. At a minimum, we should recognize that government 


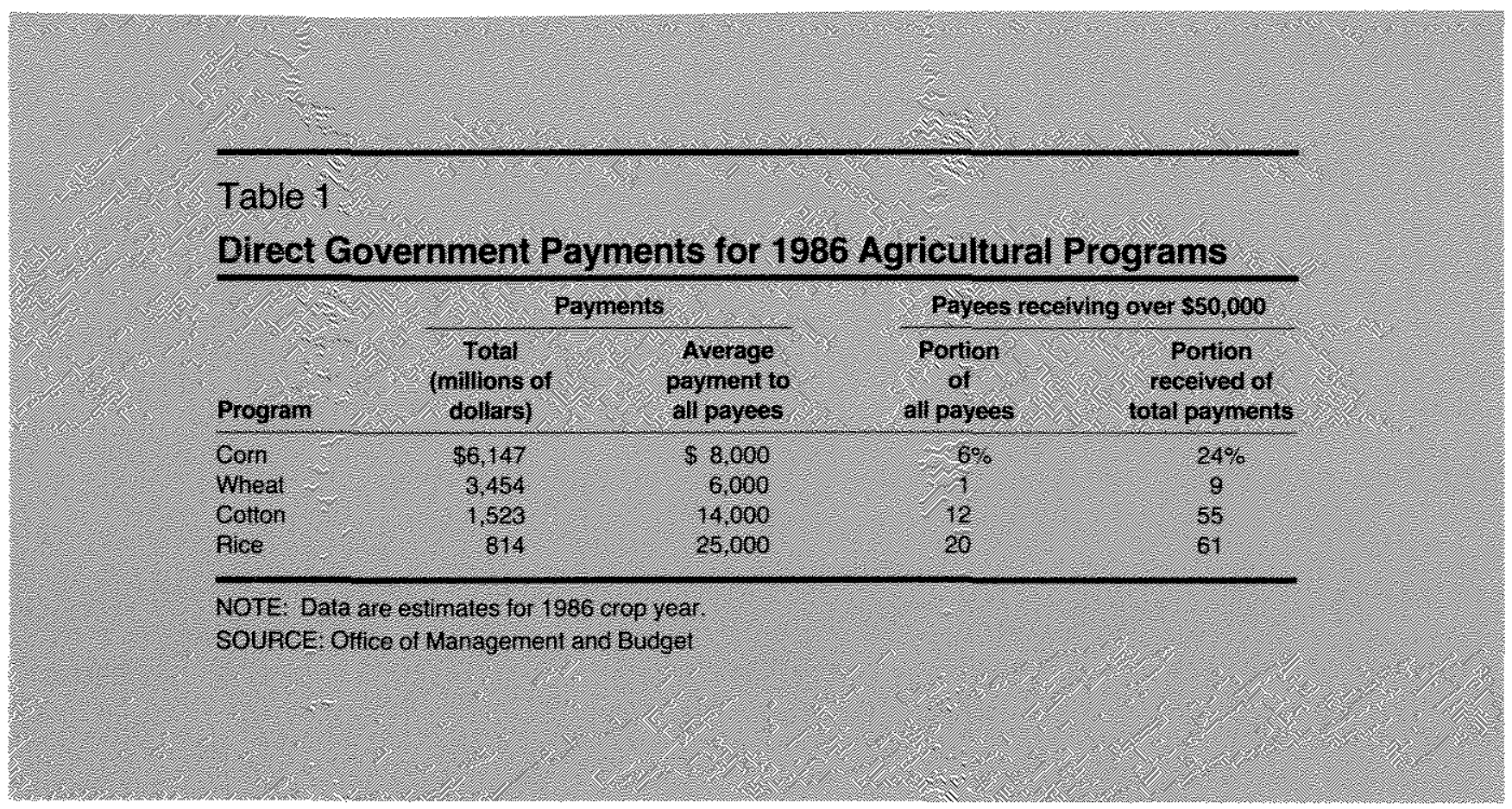

failure exists and must be balanced against market failure. For example, the principal reason that a private-sector mechanism for hedging risks has not been developed is government's heavy involvement in agricultural affairs. That is, government has provided price and income insurance to farmers at little or no cost, and this involvement has acted as a deterrent to the private sector supply of comparable insurance. Only recently are option markets being developed that allow farmers to purchase, in competitive markets, insurance against price decline.

Moreover, government intervention can often increase, rather than decrease, the agricultural sector's risk. Unstable monetary and fiscal policies increase risk. Trade embargoes, which may be imposed suddenly, increase risk. Constant changes in farm policy increase risk. Studies by the World Bank, for example, show that protectionism exaggerates fluctuations in farm prices. Government policies generate huge surpluses, which are stored and overhang the market, again increasing risk. Once it is recognized that government is not a perfect instrument for correcting market failures, we should turn to other schemes.

A related element that lies behind many programs is the idea of preserving "the family farm." Congress often talks about the family farm as being the backbone of all that is noble and truthful in America. We can smile a little bit about this, but the small family farm is part of the ideal Jeffersonian society. The trend in agriculture, however, is toward fewer and larger enterprises run like commercial businesses. Most family farms now earn a significant portion of their income off the farm; hence, the applicability of this rationale has diminished. In fact, farm policies, as currently designed and administered, do very little for the family farm.

Another rationale for government intervention has been conservation of resources and environmental issues. There often exists a difference between the interest of societies at large and farmers in terms of land use and water resources, pollution, erosion and common property problems. Generally, higher support prices have induced marginal land into production; occasionally, however, programs such as the current Acreage Conservation Reserve have retired land from farming. Finally, there has been a concern about food security and reasonable consumer prices for food products. Specifically, subsidies to agriculture have been viewed as a way to increase production and, therefore, lower prices to benefit consumers, particularly low-income consumers. Also, it has been argued that government intervention in commodity markets can alleviate temporary supply shortages or provide a degree of self-sufficiency in agricultural products for the nation as whole. As we all know, programs have worked to increase production, but not to lower prices. Moreover, even if the prices of some specific commodities are lowered, consumers pay the cost of increased production or food reserves through higher taxes. 


\section{RENT-SEEKING BEHAVIOR OF FARMERS}

Regardless of the particular justification for agricultural policies, however, they are currently supported principally by what economists call rent-seeking behavior. Rent seeking might be defined simply as the personal interest of a vested interest group in getting more income. In agriculture, many commodity groups have much to gain from higher support prices, production restrictions or quotas and tariffs on imports. Moreover, potential gains from such restrictions are large enough to induce groups to organize and incur the costs of lobbying for their adoption.

Because farm lobbies are very powerful, the results of rent-seeking behavior by farmers have been quite predictable. Perhaps most visible is their effect on the U.S. budgetary exposure. Last year (fiscal 1986), the U.S. government spent some $\$ 40$ billion on agriculture and related programs. This is an enormous budgetary cost that has expanded dramatically in the last few years. This large cost to the budget has been compounded by billions of dollars in consumer costs due to higher food prices. Given the incentives to produce under the stimulus of large govemment subsidies, the supply management bias of current programs has been doomed to failure. Stimulating production with higher target prices and fighting the predictable surpluses with acreage diversions ensure only higher taxpayer costs. Restricting output with diversions or set-asides of controlling quantities of product sold in fresh or processed form, as under marketing orders, raises food prices to consumers. Policies that attempt to restrain production through land controls also have the effect of making our farm product less sellable in the world market and reducing our exports.

\section{THE FAILURES OF FARM POLICIES}

Federal farm programs simply have failed to address the economics of social problems used to justify the aid. Farm programs do not reduce risk or reduce food prices to consumers, Moreover, as shown in charts 1 and 2 , the billions of dollars of aid provided is not targeted to farmers with large debt or cash flow problems: most farmers under financial stress are in the family-farm class of $\$ 40-\$ 100$ thousand in ammual sales, but most payments go to farms with more than $\$ 500$ thousand in annual sales. Also, we should not forget that the benefits of farm programs are capitalized into higher asset values so that, in the long run, the only true beneficiaries of fam programs are land. owners who owned their farms prior to the adoption of a farm program or an increase in its benefits.

Much of the money spent on agriculture does not go to distressed farmers, of course, because federal farm subsidy payments are proportional to production. The largest famers gain the largest share; thus, the government (taxpayer) assistance does not go to those most in need. In fact, as many of us have read, the largest farmers, those who get the biggest benefits, are often the richest: one farmer last year got a check for $\$ 12$ million.

Current policy also results in economic waste. Because the subsidies are tied to production, there are incentives to overproduce. The stock of surplus commodities is left unused or sold at prices below its cost. Excess production, which must be stockpiled by the government or dumped onto world markets, imposes economic losses either through inefficient use of land of restrictions on production. Domestic and world prices are depressed as a result of these government policies, which, of course, is something we are trying to offset with higher loan rates and target prices. It also is interesting to note that similar policies in other countries have given their farmers the same signals to overproduce, generating ever-expanding worldwide grain surpluses (chart 3). The adverse side effects will be eliminated only when the incentive to produce for the government is replaced by incentive to produce for the market.

Government policies also have led to other dramatic effects not directly observable in program expenditures. Studies show that there are large costs of subsidized production due to misallocation of resources in the economy as a whole: large costs to the consumer, large financial cost to taxpayers and significant deadweight social costs. Agricultural policies result in a greater commitment of resources to that sector than will be generated in a free market. To subsidize agriculture, other sectors are implicitly taxed. Resources are drawn out of other sectors, notably industry, to the agricultural sector. Some say that this shifting of resources has contributed to the "deindustrialization issue." In fact, some studies suggest that Europe has sacrificed up to one million manufacturing jobs due to its agricultural programs.

There are also macroeconomic effects. Money and commodity markets are linked. Shocks from one market spill over into the other in terms of price changes and output. These policies have had a dramatic effect, for example, on land prices. In some countries, such as Japan, they've had significant effects. Japanese agricultural policies have effectively bid up the price of 


\section{Chart 1 \\ Distribution of Financially Distressed Farms by Sales Class, January 1, 1986}

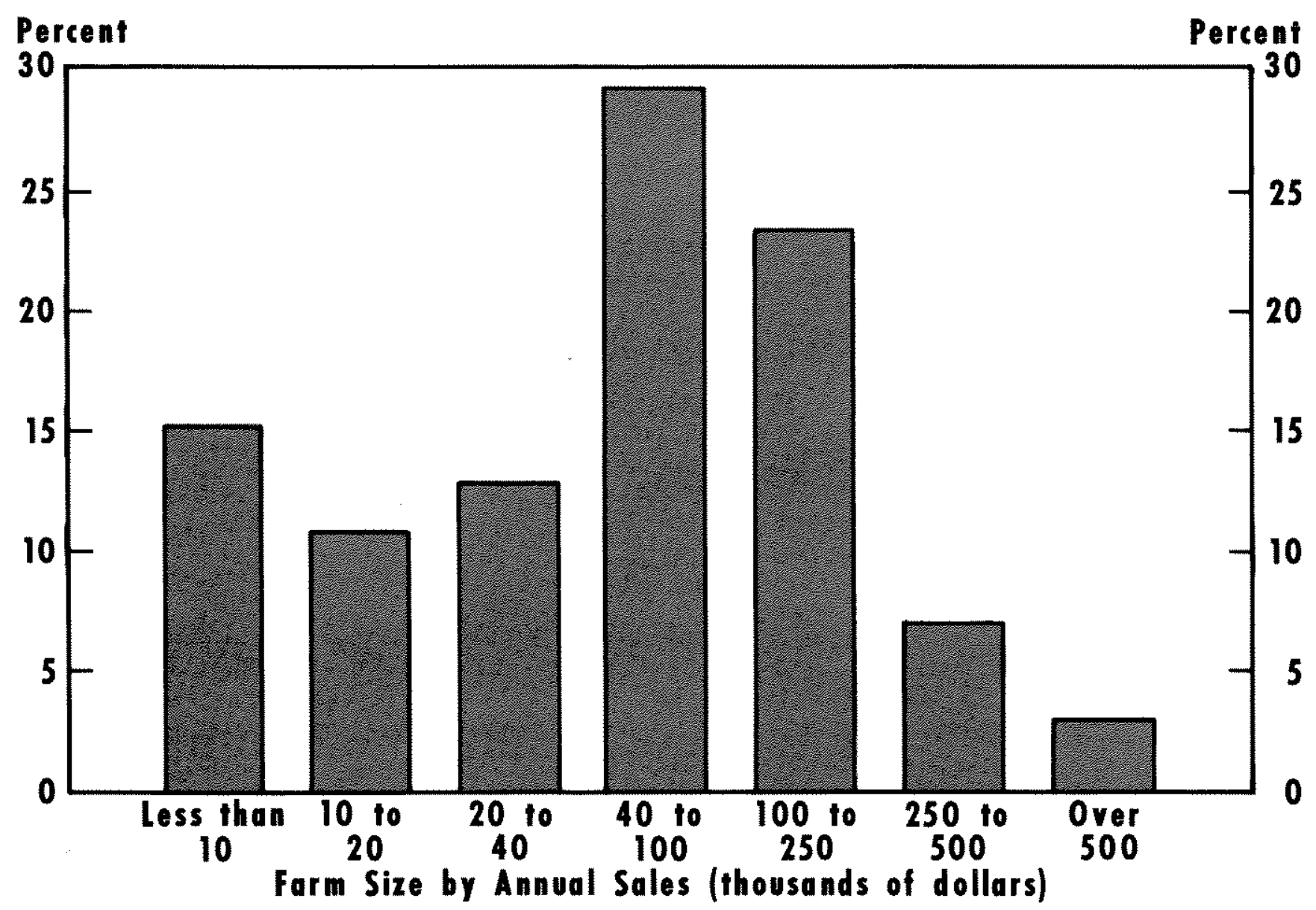

NOTE: Financially distressed farms are defined as those with debt/asset ratio over 40 percent and negative cash flow.

Source: U.S. Department of Agriculture

land in Japan and increased housing costs substantially. The European Common Market has developed programs to subsidize the export of its surplus farm products and, as a result, we have the export enhancement program in the United States, which subsidizes our agricultural exports. So, at this point we are into a "subsidy war" with the Common Market, Other com" mercial exporting countries have been caught in the crossfire of this subsidy war. Recently, we've subsidized the Soviet Union in grain sales, and it now will be true that one can buy grain cheaper in Moscow than in Chicago. We developed the marketing loan concept for rice, which effectively subsidizes the export of rice abroad; this has hurt the market for Thailand, one of our major allies in Southeast Asia. This war of subsidies now is hurting not only our taxpayers and other exporting countries, but is benefitting the main importers, such as the Soviet Union, The result is a set of farm programs that contradicts many of our foreign policy objectives. 


\section{Chart 2}

\section{Average Direct Government Payments per Farm by Sales Class, 1985}

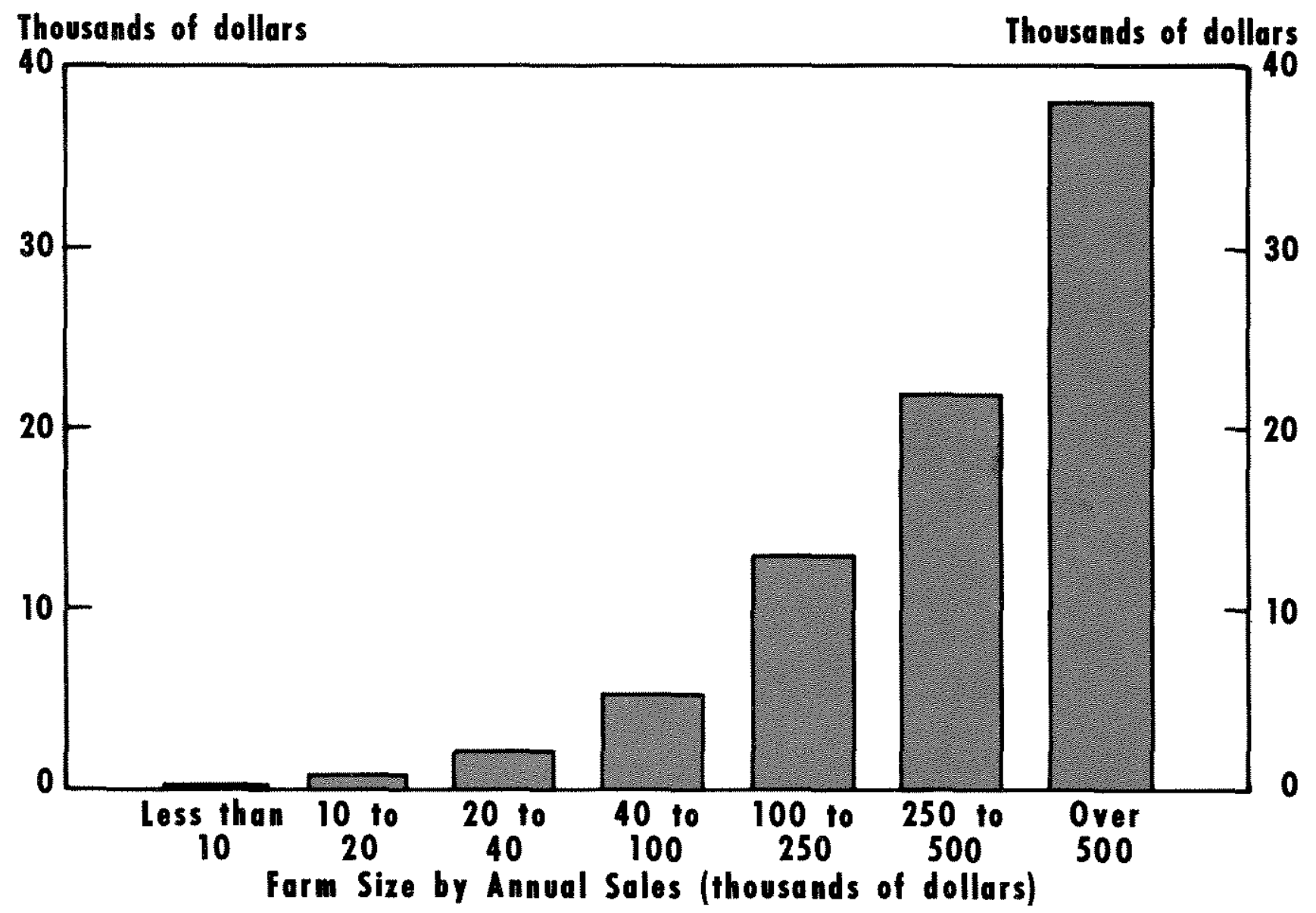

Source: U.S. Department of Agriculture

\section{THE PROSPECTS FOR REFORM}

In matters of farm policy, as the comic strip character Pogo used to say, "We've identified the enemy and it is us." As we've seen, domestic programs have been justified by a variety of concerns but remain in place largely because of special economic interests. Although these policies have resulted in great and costly economic distortion, I would suggest that focusing reform on U.S. domestic farm policies alone, in terms of their design and cost, has not been a fruitful way to go and won't work in the future. The U.S. must recog. nize that our agricultural sector is inextricably bound with the world's agriculture trade, economic growth and policies of other countries. U.S. farmers and those interested in farm policy must deal with the fact that international forces play a critical role in determining fam prices, income, exports, imports and the health of our agricultural sector. Due to the pain associated with government price distorting interventions and the resulting chronic surpluses, the reform of U.S. farm programs today is widely considered a necessity. Moreover, when you start spending the monies we've been spending (the Common Market spent about $\$ 23$ billion last year, nearly as much as the United States), 
Chart 3

\section{Carryover Stocks of Coarse Grains and Wheat}

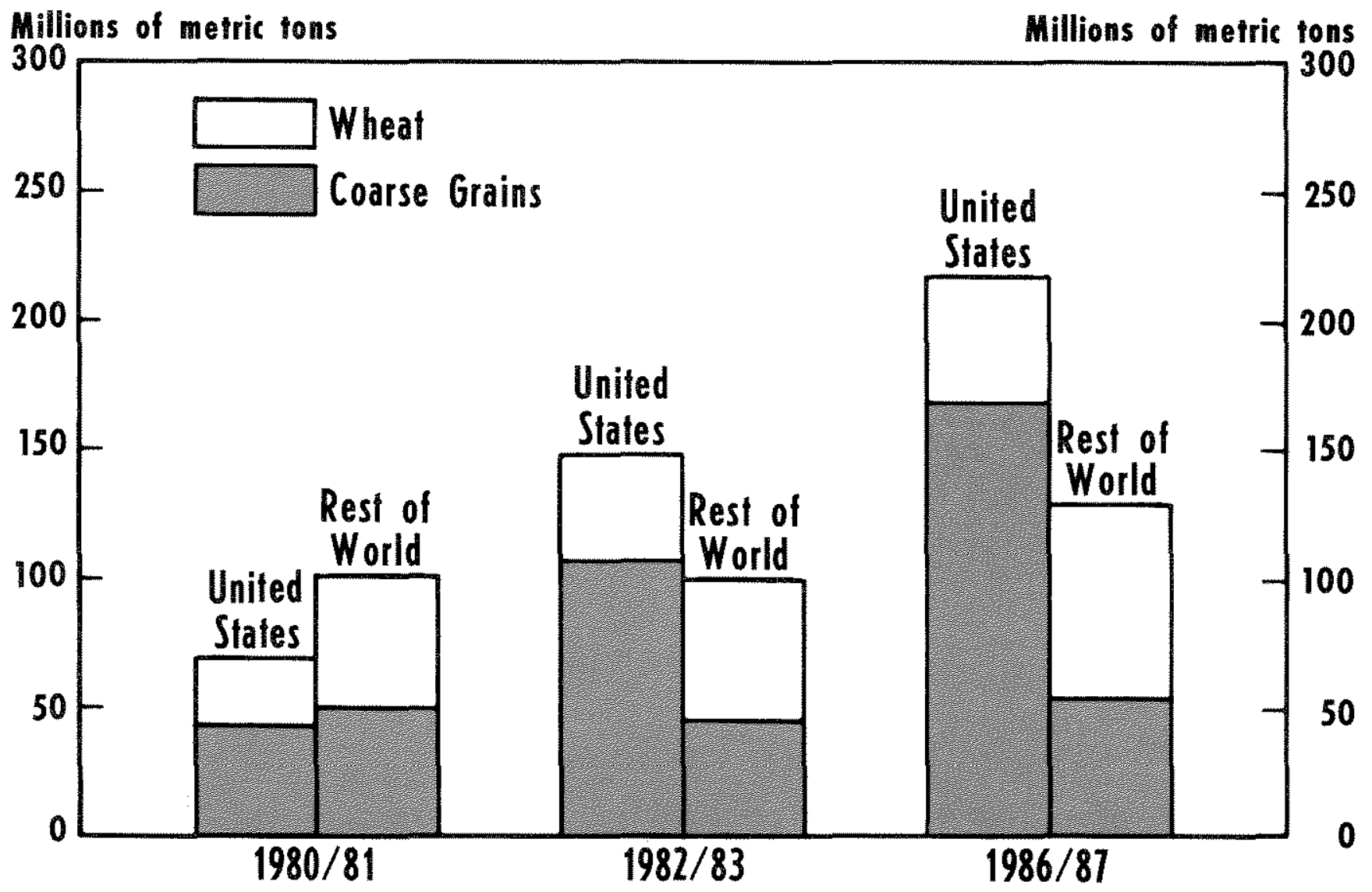

NOTE: Data are for crop years; $1986 / 87$ data are preliminary estimates.

Source: U.S. Department of Agriculture

there is potential for reform of agricultural policies in other countries as well. A brief summary (table 2 ) of farm programs in effect in the United States and abroad clearly indicates there is plenty of reform to be adopted by all.

Last year at the 'Tokyo economic summit, world leaders agreed that agricultural policies were in need of reform. The ministerial declaration at Punta Del Este, which launched the new GATT round of trade talks, made agriculture a top priority for reform and promised to examine both direct and indirect subsim dies affecting international trade. This spring; the secretary general of the OECD released an interim report on agriculture. It said that "the causes of the present crisis are rooted in domestic agricultural poli- cies. Key to reform is emphasis away from price sup" ports." The United States has tabled a proposal in the new GATT round to eliminate all agricultural subsidies and to allow free trade in agriculture by the year 2000 .

The approach to reform discussed most often is decoupling. Decoupling removes subsidies from production and directs farm benefits to those in need by giving them income support directly. This approach does not distort market prices and give false signals to overproduce; thus, the surplus problems are eliminated. Moreover, the aid is targeted to those in need, rather than those who merely produce the most. Finally, resources employed in agriculture will be there 


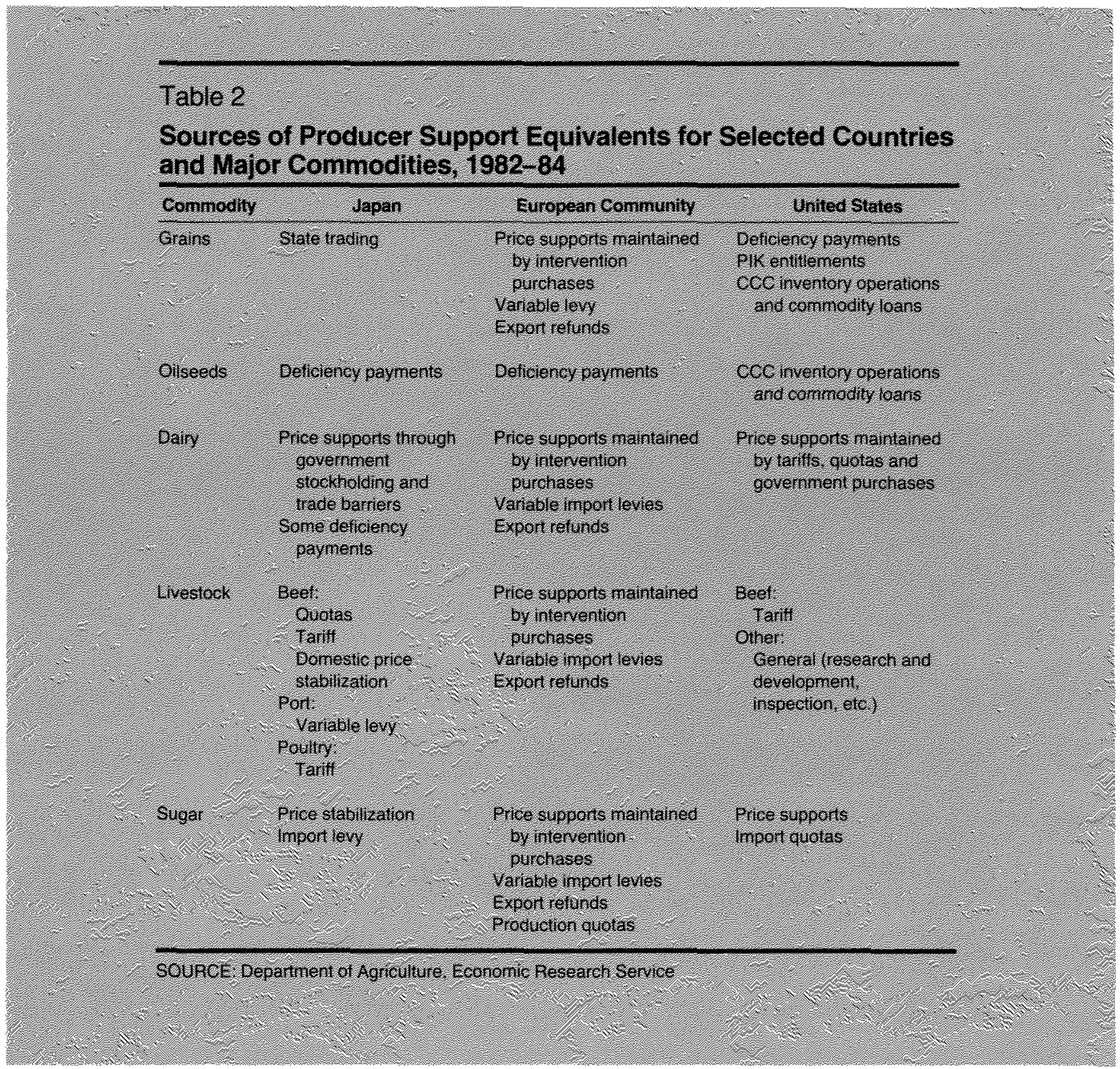

because, at market-determined prices, farm production is their highest-valued use. According to the OECD, government-induced distortions are the cause of the problem and only their removal will provide a cure. Recently, the OECD ministerial met in Paris and produced a communique on agriculture. That communique also reaffirmed that the cause of the current agricultural problems is public policy. The policies that prevent an adequate transmission of market signals to farmers lead to rising surpluses and declining prices and farm incomes. Thus, it is now being accepted internationally that public policy is a cause of the chronic surplus.
The communique also provided guidelines for reform. First, a long-term objective is to allow market signals to influence the orientation of production, which will better allocate resources. Second, consideration must be given to non-economic factors such as food security. Third, the communique endorsed decoupling, that farm income support should be made through direct income support targeted to farmers in need and not linked to production.

Critics of such proposals argue that the immediate costs to famers of dismantling the protection af forded by price supports and production controls will 
be too great. Therefore, we need to know several things about compensation schemes: how they can ease the pain of adjustment; how they can counter effective political opposition to reform; how compensation can be based on the losses from policy changes; and how such schemes can be designed to reduce the moral hazards that might accompany these policy changes. One example of how these compensation issues can be addressed is the administration's sugar reform package that was sent to Congress this spring. In this package, compensation is to be offered to sugar producers over a four-year period of time in exchange for lower support prices. Compensation will be costly -in the multiple millions of dollars for some sugar producers - but the distortions and long-run cost of sugar programs that could be reduced provide benefits way in excess of these short-run payments. And, in fact, it is possible to compensate farmers for giving up their price supports and at the same time benefit both consumers and taxpayers. 